\title{
Learning Values Model in Early Childhood Education: A Case of a Nature School in Central Java, Indonesia
}

\author{
Fauzi $^{1 *}$, Ifada Novikasari $^{1}$ \\ ${ }^{1}$ Faculty of Tarbiyah and Teacher Training, IAIN Purwokerto, Purwokerto, Indonesia \\ "Corresponding author. Email: fauzi@iainpurwokerto.ac.id
}

\begin{abstract}
Values based education is currently a concern in the development of contemporary education. Some schools have applied indoor or outdoor values education. Outdoor education is an interesting option since students may directly interact with the environment. This article aims at introducing values based nature school learning model in one of early childhood nature schools in Indonesia. Employing Miles and Hubermen's analysis model, this case study research is conducted interactively and continuously to obtain an overview of values based learning model applied in the school. The research results show that learning plan consists of one-year activities program in spider web shaped format; semester plan, weekly plan, and daily plan. Values education learning is conducted with real and direct activities application, modelling, and habituation. All activities of values education learning is conducted with integrated thematic learning model in all of educational activities. The evaluation system is with authentic assessment approach. Learning outcome is evaluated in five processes, consisting of daily evaluation, weekly evaluation, quarterly evaluation, semester evaluation and annual evaluation.
\end{abstract}

Keywords: learning model, value, early childhood, nature school

\section{INTRODUCTION}

Referring to [1] an expert and activist of values education with his LVEP (living values education program) program, it is described that the world is currently facing life values crisis. This crisis includes, among others, weak peace, appreciation, love, tolerance, honesty, modesty, cooperation, happiness, responsibility, simplicity, freedom and unity. The cause of the value crisis is because values of universal life are not be the main grip and not implemented in the human life. To break the chain of value crisis regeneration needed a value education process that can motivate and build awareness, as well as create the practice of universal life values in daily life.

The condition and reality of the problem are not implementing the value in of life as described above because learning practices tend to be very strong in emphasizing aspects of knowledge. While aspects of attitude and skills do not get adequate reinforcement [2].

According to [3], knowledge is continuously obtained personally and through experience in the environment. Various learning practices in the context of educational values have been presented in the world of education with various patterns or models. These models derived from the same anxiety about the crisis of values as the above explanation while referring to the situation and condition as well as their locality. The existing models continue to inspire educational researchers and practitioners to continually find appropriate and contextual formulations as guidelines for implementing learning by basing on existing best practices carried out by educational institutions. So that efforts are needed to find and build various formulas of value education learning models for early childhood that have been practiced by early childhood education institutions with their specificities, uniqueness, and locality. Therefore, nature based continuous education may become an option [4].

According to [5] and [6], interaction with nature may develop students' values. The reason is that such interaction and experience gained may provide students with wide opportunity to develop their personal knowledge and development [4], encourage their sense of responsibility [7], and environmental care [8].

Education is an effort to provide students with knowledge, since education is given to promote a change in behaviour and to provide citizen with competencies required for sustainable life. Nature school may become part of formal education of all levels [9], one of which is early childhood education level. According to [10], many people are currently interested in outdoor learning, since it does not only develop students' cognitive skills, but also their physical and psychological skills [11].

Value education must be done from an early age as the most fundamental phase in human life. Early age as the phase of golden age from human life must be utilized as optimal as possible because it will never be repeated throughout the span of human life. According to Montessori the child's brain is very easy to accept and absorb (absorbent mind). In addition, early childhood is seen as a critical period and sensitive period in all stages of child development. This condition of early childhood will be more open to learning certain behaviours and can learn specific skills more easily [12]. If this period does not get the right stimulation of learning, it is certain that the child's growth and development will experience obstacles and even failures. Therefore, it is necessary to formulate an appropriate 
learning model in accordance with the characteristics of early childhood development so that the strengthening of value education can be successful.

With regard to the effort to find values education learning model for early childhood, Taman Kanak-Kanak Sekolah Alam Baturaden (TK SABar) is an interesting early childhood institution to be studied with its learning model located in and integrated with a forest area. Based on initial research in the nature school, the universal values education for early childhood students is typical and unique compared with those of other early childhood institutions. Among its typicality and uniqueness, this Kindergarten is located in Baturaden resin tree forest area with its building in the form of gazebo integrated with forest environment; its learning activities are performed in an open environment around resin tree forest of Perhutani Baturaden and other learning objects are in surrounding social environment.

Learning in TK SABar is, both in theme implementation and process aspects, always directly associated with real and direct life in open environment. Therefore, learning is truly based on real experience in integration with the nature. The learning process is able to educate students of such life values; for example, when a student is having lunch during break, a cat comes approaching, and he/she spontaneously give some of his/her rice and side dish to the cat. Questioned about why he/she gives the food to the cat, the student answers: "poor it...just let it eat too...it's hungry...we should share some with animals..." while his/her hand petting the cat. This conforms to the opinion of [13] that interaction with the nature may support imaginative play and positive relationship development.

It is interesting to study about reality of values education for early childhood in TK SABar as explained above in order to formulate a learning model to be taken as practical reference for values education for early childhood. Besides, it is naturally interesting to perform this study as an effort to reveal the substance of direction of learning process and result as genuine local product with its best practice in application of learning model in integration with the nature.

\section{RESEARCH METHOD}

This case study research is conducted with Taman KanakKanak Sekolah Alam Baturaden (TK SABar). This research was conducted by exploring and describing existing reality in the community of TK SABar along with its learning dynamics and activities.

Observation, interview and documentation are conducted to collect the data. Observation was carried out by observing teaching and learning activities from children coming to school until back to home to get information about children's learning activities, especially related to the learning process of values, patterns of interaction that are built, situations and conditions of teaching and learning activities, learning atmosphere that is built in TK SABar, and its learning evaluation system. Interviews were conducted to find out the basic thinking of selecting a nature-based learning models, curriculum developed, management of institutions, networks that were built. In the documentation study, researchers will explore information from documents owned by TK SABar. Documents that will be used as data sources include TK SABar profile documents, student master books, child learning progress reports, learning planning documents (semester program, RPPM, and RPPH), teacher data documents, school organizational structure documents, photographs of TK SABar activities, children's work, and other related documents

The data are analyzed using Miles and Hubermen's analysis model [14], namely: data reduction, data display, conclusion drawing and verification. Activities in qualitative data analysis are conducted interactively and continuously until completion during data collection and after data collection within certain period, until no new data or information are collected.

\section{RESULTS AND DISCUSSION}

TK SABar takes is indoor and outdoor learning environmental settings. For indoor setting, class building is called Saung (gazebo). Saung is a place of learning semipermanently constructed from wood. This saung is integrated with forest environment. According to the research conducted by [15], nature school provides students and teachers with opportunity to interact and study by eliminating spatial boundary. By integrating indoor and outdoor learning, TK SABar conforms to [16]'s opinion that outdoor learning may, besides developing positive attitude towards oneself, others and environment, also grow positive attitude towards indoor learning.

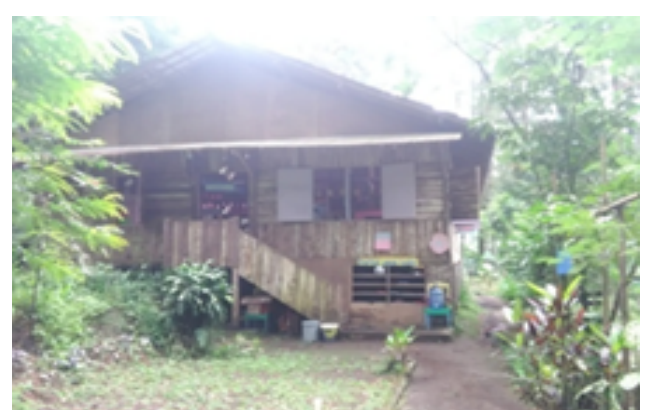

Figure 1 Saung's TK SABar in Forest Environment

\subsection{Learning and Education System}

The basic principle of learning system implementation is to provide the best environment to drive children's both motoric and mental-psychological developments. The nature serves to be a true teacher that gives much knowledge in every place and occurrence. TK SABar's learning principles are: (a) Students learn under responsible freedom; (b) Students may develop their curiosity \& creativity, students learn happily since learning is a necessity; (c) Learning with fun learning, free learning \& experimental learning methods; (d) Students serve to be center of class.

The learning methods applied by TK SABar are, among others: (a) Exemplary/ giving applicative example; habituation: "practice makes perfect" without burdening; (b) Outing \& Research: Observe natural condition and 
phenomena. As in [17]'s study nature school guides skill practice which may build an understanding of the nature and associate it with human; (c) Out-bound: playing/ height attraction/ low impact, tracking (cross-country) and caving in order to shape students' mentality. Nature school in its practice performs exploration and discovery using all senses [18]. The research conducted by [19] also shows that nature school influences students' mental health and physical activities.

\subsection{Nature Based Values Education Learning Model}

TK SABar's curriculum structure is formed in a Spider Web shape with its center in the form of theme learned and branches as spread materials. Spider Web is then detailed into semester plan, weekly plan and daily plan. The theme covered in learning includes five contents: Moral Theology (Akidah Akhlak) \& Leadership: Introduce and instill akhlakul karimah (noble character); Logic \& Creativity: Stimulate logical thinking ability and develop creativity; Talents \& Life Skill: Explore and facilitate students' interests and talents as the base to choose specific abilities \& develop their life skills; Communication \& Social Skill: Train students' ability to socialize, communicate and adapt with peers and surrounding people; Self Help \& Physical: Train independence \& self-assistance as well as physicalmotoric abilities. Theme here means natural environment, with theme given may develop children's five contents. Nature knowledge may develop their knowledge of Islam, noble attitude (akhlaq), and understanding of human's role in good nature management. The theme given may develop students' logical thinking ability of the law of cause and effect in the nature and creative thinking to take a role in environmental issue. The activities may develop students' life skills and talents. In addition, the social environment encourages their social and communication skills. All of TK SABar's activities are performed under 'learning while playing principle', which may encourage students' independence and their physical-motoric development. The method which used on learning process as nature learning consist of: learning with nature by using the potential of natural resources; learning with nature involving culture or local wisdom; learning by exploration the nature; study by experiment the nature; and learning by outing.

Compared with [20]'s environment based learning model, it is education held in environment and for environment, education associated with social issue, action oriented and critics. This conforms to TK SABar's model which contains creativity and logic components as well as talent and life skill.

Learning activities in the nature school of TK SABar involve learning in the classroom and outside the classroom. This is learning done in Saung.

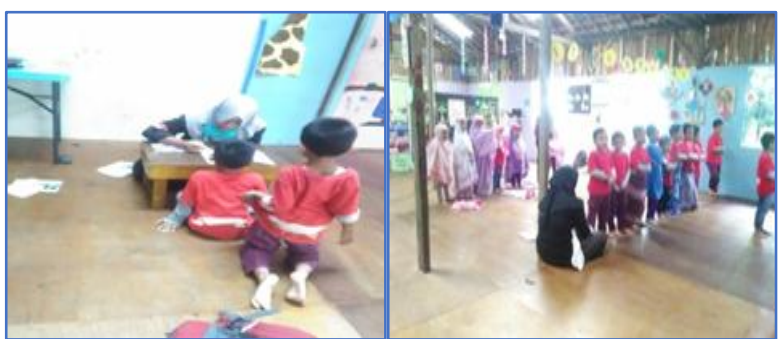

Figure 2 Value based Learning Activities in Saung

Learning that is done outdoors is adapted to the theme in the learning program. The following is a picture of outdoor student activities.

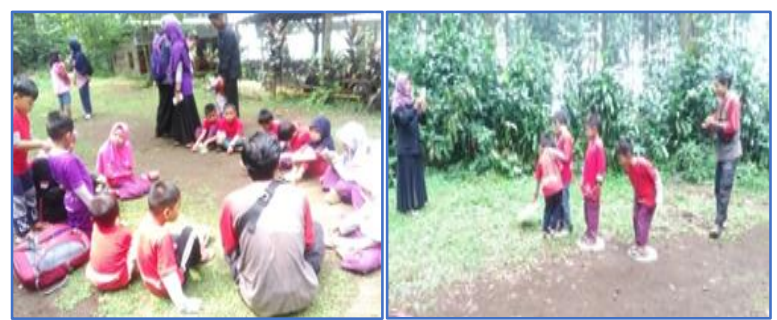

Figure 3 Value based Learning Activities in Outdoor

Model of outdoor learning identifies five domains of children development [16], among others are covering cognitive, physical, social, emotional, and personal domains. There is similarity between the five domains and the five learning contents of TK SABar. However, the difference is that TK SABar includes spiritual aspect in the form of Moral Theology (Akidah akhlak) content into its learning.

\subsection{Learning Implementation or Activity}

The essence of values education of nature school is its learning implementation. Nature based learning applied by TK Alam Baturaden is based on the National Curriculum enriched with nature school's curriculum, which is not merely outdoor learning, but also learning while utilizing anything existing in the nature while associating them with Al-Qur'an and Hadist. Nature based learning takes learning while playing as its principle, in which playing is children's world, so that they will get to have an understanding quickly [21].

Spiritual value is one value education instilled in TKSBar. Interaction in the nature activity is always associated with Al-Quran and Hadist. Referring to [22] proposes that experience cannot be divided into physical and spiritual parts, since human always views issues from physical object. Therefore, in TKSBar, knowledge and experience are obtained through observing objects to be associated with spiritual perspective.

Anything around us, if we want, may be learned, in which we can recognize anything in the nature. When we are sensitive enough, the nature actually teaches us many things. Nature based learning is to maximize what Allah has created in our surrounding. Nature school eliminates class physical constraint and pedagogic constraint in national 


\section{ACKNOWLEDGMENT}

learning environment [15].

\subsection{Learning Evaluation System}

Evaluation is an activity performed by class facilitator (teacher) to observe to what extent students' understanding of certain theme, subtheme and material is. Evaluation is implemented with authentic assessment approach. Authentic assessment is performed as a learning assessment referring to a situation or context in real world. In a learning process, authentic assessment measures, monitors and assesses all learning outcome aspects (covering cognitive, affective, and psychomotor domains), either perceptible as final outcome of a learning process or in the form of change in and development of activities, and the outcome of both indoor and outdoor learning processes. Evaluation is performed as an integral part of indoor learning, reflection of real world, using many measures, methods, criteria, both comprehensive and holistic. This evaluation is performed in some aspects, namely: performance task, deliverable, activity, personality and attainment. In addition, daily evaluation is also performed by parents at home using connecting book.

Connecting book serves to be a media for parents to give information of the development of children's activities at home, such as reading Al-Qur'an, recitation, Dhuha prayer, and achievement at home. For example, a teacher writes in connecting book; "Alhamdulillah, the child recognizes colors well. What parents should do at home is to accompany the child to learn coloring with correct color choice", and from such note, parents are to accompany and guide the child and the results are to be written in connecting book as feedback as well as follow-up to teacher's note.

\section{CONCLUSION}

Values education learning in nature school of TK SABar is applied through combining learning with indoor (saung) and outdoor in the nature, on a rational base: first, it serves to implement religious orders; second, deconstruction of conventional educational system and practice; third, a new flow of alternative education which conforms to students' and environment's condition and context. Learning plan consists of one-year activities program referred to as long term plan, designed in a spider web shaped format; semester plan, weekly plan and daily plan. Anything taught are arranged in the frame of local wisdom with integrated thematic learning model covering all aspects developed, learning method, school's physical environment, interaction situation created between all educational elements, and exemplary aspect as the most effective media in values inheritance.
This research was supported by research funding DIPA from IAIN Purwokerto.

\section{REFERENCES}

[1] D. Tillman, "Living Values Activities for Young Adults," Deerfield Beach-Florida: Health Communications, 2000, p.ix

[2] S. Akbar, "Model Pembelajaran Nilai dan Karakter Berbasis Nilai-Nilai Kehidupan di Sekolah Dasar," Jurnal Ilmu Pendidikan, 2010, 17(1), 46-54.

[3] D. A. Kolb, "Experiential learning theory and the Learning Style Inventory: a reply to Freedman and Stumpf," Academy of Management Review, 6(2), 1981, pp. 289-296.

[4] H.R. Hungerford and T. L. Volk, "Changing learner behavior through environmental education," The Journal of Environmental Education, 21(3), 1990, pp.821.

[5] J. Palmer, J. \& P. Neal, "The handbook of environmental education," London: Routledge, 1994.

[6] Bogner, "The influence of short-term outdoor ecology education on long-term variables of environmental perspective," Journal of Environmental Education, 1998, 29(4), 17-29.

[7] E. Jeronen, J. Jeronen, J., H. Raustia, "Environmental Education in Finland - A Case Study of Environmental Education in Nature Schools," International Journal of Environmental \& Science Education, 2009, 4 (1), 1-23.

[8] C. Turtle, I. Convery, K. Convery, "Forest Schools and environmental attitudes: A case study of children aged 8-11 years," Cogent Education, 2015, 2, 1-14. http:// dx.doi.org/10.1080/ 2331186X.2015.1100103

[9] R. Joyce, "Outdoor learning: Past and present," Milton Keynes, UK: Open University Press, 2012.

[10] H. Elliot, "Forest School in an inner city? Making the impossible possible," Education 3-13: International Journal of Primary, Elementary, and Early Years Education, 2014. Doi: 10.1080/03004279.2013.872159.

[11] A. Faber Taylor, F. E. Kuo, "Is contact with nature important for healthy child development? State of the evidence," In C. Spencer \& M. Blades (Eds.), Children and their environments: Learning, using and designing 
spaces, Cambrdge, UK: Cambridge University Press, 2006.

[12] G. S. Morisson, "Early Childhood Education Today,"Pearson, 2018.

[13] K. Dowdell, T. Gray, T., \& K. Malone, K., "Nature and its influence on children's outdoor play,"

Australian Journal of Outdoor Education, 2011, 15(2), 24-35.

[14] M. B. Miles, A. M. Huberman, "Qualitative data analysis: an expanded sourcebook (2nd edition),"

London: Sage, 1994.

[15] F. Harris, "The nature of learning at forest school: Practitioners' perspectives," Education 3-13, 2017, 45, 272-291.

[16] K. Malone, "Every esperience matters: An evidence based research report on the role of learning outside the classroom for children's whole development from birth to eighteen years," Report commissioned by Farming and Countryside Education for UK Department Children School and Families, Wollongong, 2008.

[17] E. Kolbert, "Spoiled Rotten, why do kids rule the roost," The New Yorker, Retrieved July 19, 2012, from http://www.newyorker.com/ arts/critics/ books/2012/07/02/120702crbo_books_kolbert.

[18] S. Knight, "Risk and adventure in early years outdoor play: Learning from Forest Schools," London: Sage, 2011.

[19] R. Lovell, \& J. Roe, "Physical and mental health benefits of participation in forest school," Countryside Recreation Network, 2009, 17, 20-23.

[20] J. A. Palmer, "Environmental Education of the 21st century: Theory, practice, progress and promise," pp. 267-277. London: Routledge, 1998.

[21] S. Waite, S. Rogers, \& J. Evans, "Freedom, flow, and fairbess: Exploring how children develop socially at school through outdoor play," Journal of Adventure Education \& Outdoor Learning, 2013, 13(3), 255-276.

[22] M. Käpylä, "Ympäristökasvatus koulun oppimisja tiedonkäsityksen muuttamisen välineenä. (EE as a tool when changing learning and information conception.)" In S. Ojanen \& H. Rikkinen (Eds.), Opettaja ympäristökasvattajana (pp. 24-39). Porvoo: WSOY, 1995. 